\title{
Tactical mediatization and activist ageing: pressures, push-backs, and the story of RECAA
}

\section{Kim Sawchuk}

MedieKultur 2013, 54, 47-64

Published by SMID | Society of Media researchers In Denmark | www.smid.dk The online version of this text can be found open access at www.mediekultur.dk

This case study examines the incorporation of digital media technologies and practices into Respecting Elders: Communities Against Abuse (RECAA), an organization of activist elders. By studying RECAA's specific transition and following the work of Michel de Certeau (1988), I distinguish between tactical mediatization and strategic mediatization. Organizations such as RECAA must negotiate with political, ideological, administrative, and economic agendas that exert pressure and provide incentives for organizations "to mediatize" in order to survive in the current Canadian context. 'Tactical mediatization' is used to understand RECAA's very deliberate and considered response to these pressures. This distinction provides a framework for conceptualizing how activist organizations such as RECAA struggle to exert agency within meta-processes that place mounting and insistent pressure on the organization to incorporate digital media technologies into its mandate and system of values.

\section{Introduction}

Respecting Elders: Communities Against Abuse (RECAA) is a group of Montreal seniors, ranging from 65 to 92 years of age, whose mandate is to raise awareness of the many subtle ways that elder abuse operates in families and communities. Established ten years ago as a response to a lack of sensitivity on the part of government agencies dealing with older adults 
from various cultural communities and linguistic backgrounds, RECAA's primary form of communication has been face-to-face encounters and techniques drawn from Forum Theatre, the most often used 'tool' in the 'Theatre of the Oppressed' method (Boal, 1979; 1982). A short skit fictionalizing everyday life stories of elder abuse - subtle disrespect, willful neglect, physical intimidation, or financial exploitation - is presented by RECAA actors. RECAA has chosen to present these skits non-verbally in order to reach as many communities as possible. Audience members are then encouraged to become "spect-actors"1 by coming up on stage, replacing the central character, and trying out their solutions to the situation. In this way, through active intervention followed by discussion, the audience can examine how to re-write the scene to find solutions to complicated, emotionally charged situations. RECAA does not consist of older adults who are "actively ageing", the new governmental mantra that has gone global (WHO, 2002) with the realization that the world's population is ageing at an unprecedented rate. The women and men of RECAA are ageing as activists and providing a welcome alternative view of spirited oldness.

Over the past year, the members of RECAA collectively decided to engage with digital media technologies and to generate their own content for future distribution through social media and the World Wide Web. This year-long transition from an exclusive practice of face-to-face communication to the careful incorporation of digital media is the specific topic of this paper. Exploring mediatization as a meta-process and digital storytelling, this case study posits the study of transitions as key moments when the complexities of mediatization at a local level are revealed. By studying this particular transition and by following the work of Michel de Certeau (1988), I distinguish between tactical mediatization and strategic mediatization. Organizations such as RECAA must negotiate with political, ideological, administrative, and economic agendas that exert pressure and provide incentives for organizations 'to mediatize' in order to survive in the current Canadian context. 'Tactical mediatization' is used to understand RECAA's very deliberate and considered response. This distinction provides a framework for conceptualizing how activist organizations such as RECAA struggle to exert agency within meta-processes that place mounting and insistent pressure on the organization to incorporate digital media technologies into its mandate and system of values.

\section{Mediatization as storytelling and meta-theory}

The theory of mediatization has been much debated over the past years since its introduction and translation into English from research in Germany and Scandinavia (see Couldry, 2008; Livingstone, 2009; Hepp, 2012). Mediatization theorists and practitioners engage with a wide range of scholarship in media studies, including mediazation from the historical sociology of John B. Thompson (Thompson, 1985; Hepp 2012); media logic, drawn from David Altheide and Robert Snow (Altheide and Snow; 1979; Lundby, 2009); medium theory from Marshall McLuhan and Harold Innis (McLuhan, 1964; Innis, 1951; Krotz, 2009); the dif- 
ferences and distinctions between mediation and mediatization (Hjarvard, 2008; Couldry, 2008; Lundby, 2008; Kaare and Lundby, 2008; Livingstone, 2009); and more recently, media assemblages from Bruno Latour (Latour, 2005; Hepp, 2012). Mediatization theory, as this short survey indicates, exists in dialogue with a wide range of scholarly traditions, thereby defining its goals, revising and nuancing its premises, and addressing the specificities of the case studies generated in different national and transnational contexts.

Two aspects of these discussions are germane to this case study of ageing activists, strategic mediatization, tactical mediatization, and transition. The first is the detailed work of mediatization scholars who analyze the relationship between mediatization and new forms of digital storytelling. The second is a large body of conceptual and historical research that addresses a broader sweep and time frame of transformation in the intensity, scope, and quantity of media technologization that results in a condition of mediatization.

Within the English-language literature, the 2008 anthology Digital Storytelling, Mediatized Stories by Knut Lundby is a key text in the study of mediatization related to genre and specific media forms and formats. In his introduction to the collection, Lundby proposes that amateur personal storytelling focusing on the 'me' has proliferated with the increasing ubiquity of new media tools and the growth of social networking sites. As Lundby writes, in an era of intensive mediatization, digital storytelling has taken on the following key features. They are channeled through small-scale media forms because of the generic characteristics of digital platforms, such as restrictions on bandwidth, which demand short-playing media. They are created as small-scale productions involving off-the-shelf technology. They are narrow in scope, often focusing on an individual life (Lundby, 2008).

By "intensive mediatization", Lundby refers to the increasing pressure placed on individuals and organizations to engage in a "media culture" that is short-hand for a "culture of mediatization" (Hepp, 2012). Andreas Hepp asserts that "Media cultures are cultures of mediatization: that is, cultures that are 'moulded' by the media" (2009, 140; 2012, p. 2). For Hepp and Lundby, media are influenced by, embedded in, and moulded to all forms and types of communication practices. Although one of the characteristics of a transition to a mediatized society is an 'intensification' of media, researchers such as Hepp make a strong distinction between communications and media. Communication refers to "forms of symbolic interaction" that are "socially situated" (Hepp, 2012, p. 3) while a medium is a "given technological communication medium" (ibid). Hepp delineates media as "the set of institutions and technological apparata that we humans employ to communicate across space and time" (Hepp, 2012, p. 4).

According to Hepp, mediatized cultures are those cultures "whose primary resources are mediated by technological means of communications" in ways that must be specified. No one medium can define a mediatized culture, rather there are "extremely complex arrangements of different forms of media-based communicative action" (Hepp, 2012). These actions and arrangements are made manifest in actual societies and at different levels, or ranges, of sociality: in the ways that individuals share photographs through pro- 
grams such as Picasa; in the manner that organizations such as universities set up online accounting procedures and teaching evaluations; in political campaigns that are set up to be webcast, broadcast, or covered by social media from the very initial stages of planning. Each and every one of these micro-transformations "must be described if we are to understand the specificities of media cultures" (Hepp, 2012, p. 22). Each case, however, is also presumed to be part of a larger trend, the result of a long, slow, and variegated historical and social process of instantiating these complex arrangements of technologized communications within different locations.

Complementing these discussions of the machinations of mediatization at the level of genre and form is the historical and conceptual research by writers such as Friedrich Krotz (2003), Winfried Schulz (2004), Jesper Strömbeck (2008), Stig Harvard (2008; 2008a; 2009), and most recently Hepp (2012). As Hjarvard puts it, mediatization "is primarily a development that has accelerated particularly in the last years of the twentieth century in modern, highly industrialized, and chiefly western societies, i.e., Europe, USA, Japan, Australia and so forth" (2008, p. 113). Mediatization is one of a cluster of "mega-trends" such as globalization, individualization, and commercialization that operate as powerful "meta-processes" within modernity (Krotz, 2003; 2009). In Schulz's (2004) influential rendering of the concept, mediatization is said to have four characteristics: extension, substitution, amalgamation, and accommodation. Strömbeck describes different phases of transformation (2008). In all of these instances and refinements, mediatization refers to more long-lasting changes whereby social and cultural institutions and modes of interaction morph as a consequence of growing media's influence (Hjarvard, 2008).

While all of these theorists suggest that mediatization is a 'meta-process', 'meta' does not mean 'above' or 'outside' of societies. As Hjarvard suggests, "Contemporary society is permeated by the media, to an extent that the media may no longer be conceived of as being separate from cultural and other social institutions" (Hjarvard, 2008, p.117). Hepp adds that culture, religion, politics, education, healthcare, and the arts are imbued with both a quantitative increase in media activity and a qualitative difference in what the media produces as an experience of communication (Hepp, 2009). The omnipresence, scope, and intensity of the media 'positions' media as an integral aspect of all other social and cultural institutions. From this perspective, life without technologized communications is inconceivable.

Although mediatization is characteristic of industrial societies and modernity, mediatization theorists argue that it is not a universal process with completely uniform effects. 'The concept of the 'moulding forces' of the media holds on to the idea that there are different specificities of different media we have to have in focus while researching change" (Hepp, 2009, 144). Mediatization theory, with strong roots in sociology, insists that empirical validation through historical, cultural, and sociological analysis is required to parse the logics of mediatization specific to a particular context. Hepp calls this a "contextualized approach" (2009, p. 15) that is dialectically attuned to the interplay between globalizing power and national contexts. As such, the different strands and strains of mediatization 
theory share a common commitment not only to theorization but also to case studies that unravel the complexity of changes that are specifically located within a particular place or context. Krotz has stated from the beginning that "Mediatization theory should be much more committed to empirical analysis, including the study of specific mediatization processes among different groups within the population" (Krotz, 2007, p. 31). From Hjavard's perspective, one of the tasks for researchers working in these domains is to orient researchers working on cultural phenomenon - such as entertainment, religion, and politics - to assist in their understanding of how media inclusion transforms institutions and procedures. Hjarvard explains: "Under these circumstances, the task before us is instead to try to gain an understanding of the ways in which social institutions and cultural processes have changed character, function and structure in response to the omnipresence of media" (2008, p. 105). For some, this has resulted in studies of "hyper-mediatized" events such as the Olympics (Hutchins \& Mikoza, 2010). For others, this has evolved into studies of mesolevel institutions and organizations (Hjarvard, 2008a). For others still, the task has been to see what genres and forms occur at the level of practice in distinct fields such as education (Drotner, 2009) or literary studies, where mediatization affects how one represents the self (Thumim, 2008) through new styles of narration (Nyboe and Drotner, 2009), in different mediatized worlds such as MySpace (Brake, 2008).

The emergence of these detailed empirical studies of mediatization as long-term metaprocess with documentable social consequences produce several results. Empirical case studies put the meta-theory to work, thus contributing to its legitimacy as a meta-theory by generating evidence and examples. This accumulation of detailed case studies also responds to an earlier criticism, primarily from British cultural studies scholars invested in the advantages of the term 'mediation', that the concept of mediatization is overly teleological, linear, and disconnected from real world conditions and forms of resistance to its overarching effects (Couldry, 2009; Livingstone, 2009).

\section{RECAA: communications in transition}

It is within this context that I return to RECAA (Ressources Ethnoculturelle Contre L'Abus envers les Aîné(e)s/Respecting Elders: Communities Against Abuse), a small-scale activist organization of older adults from a variety of transnational cultural communities that has been working in Montreal for over 12 years. ${ }^{2}$ As an organization, RECAA is at once a core troupe of non-professional actors and a larger 'loose' network of 100 or so members who regularly attend public events and an annual general meeting. RECAA belongs to a set of allied community-based groups, such as the South Asian Women's Community Centre, Council for Black Ageing - Montreal, Chinese Family Services, and Centre d' Orientation Paralegale et Social pour les Immigrants (COPSI), which support one another through formal and informal collaborations. Organizations like RECAA run on very small budgets. There are no paid staff and everyone volunteers. They have no 'core funding' from the 
government and no permanent location of their own. They exist on a project-by-project basis. At present, RECAA meets twice weekly at a local Montreal alternative high school. What the members of RECAA share, besides their age, is a commitment to politics, human rights, and social justice. Their entire mandate is centred on advocating for communication, reciprocity, and respect in a way that challenges the professionalization of services for older adults through gerontologically based models, which in the context of Québec, either ignore cultural communities or are unaware of their specific dilemmas due to linguistic and cultural differences. RECAA members are activist seniors, mostly women, working for and with other seniors.

RECAA practice a variant of Forum Theatre (Boal, 1979; 1982) in which members act out short skits presented without words in very localized settings, leading to discussions of alternative outcomes for older adults, who are often caught in complex situations of dependency. For example, the scene 'Aunt Enid' involves a bottle of beer, a table and chair, a crutch or walking stick, a ball cap for the actor playing the nephew, a housedress for the person playing the care worker, and a wallet to depict the action of Enid's nephew taking her money when she is not looking. This scene makes visible, or puts into form, the problem of abuse in an intimate, inexpensive, unthreatening way that encourages dialogue. After the play - which runs for 15 to 20 minutes - is over, audience members are invited to discuss what they have seen and to come up with potential solutions.

While the skits are non-verbal, relying instead on movement and gesture, the discussion is typically hosted by one of the RECAA members in French or English. If they are in a seniors' or cultural centre where there is one predominant language, then a host from the centre will act as a go-between for the group and the audience. This theatrical practice is a very direct form of 'un-mediatized' communication with other older adults concerning a sensitive topic, face-to-face, in situ. The performances are highly interpretive and abstract yet are nevertheless direct and embodied. Movements, facial expressions, and the few key props are used to build a communicative bridge between the RECAA members and their audience (see Williams, 1977; 1983; Drotner, 2009, p. 70). A culturally cultivated repertoire of gesture (Forum Theatre) accompanied by dialogue within a safe space of trust and intimacy is primary. If Forum Theatre is already functioning as a powerful way to communicate and materialize elder abuse, then why do more?

We now turn to those inter-related pressures to mediatize that either push people to migrate to a place or seductively pull them towards a new place, which the Brazilian philosopher of technology Fabio Josgrilberg calls "the digital locus" (2008). ${ }^{3}$

\section{The pressure to mediatize}

RECAA, as set of individuals and as an organization, has not stood completely outside the processes of direct and deliberate mediatization. If we return to mediatization as a long, slow process of historical change, we see evidence of the traces of different media-practices 
used by RECAA. The organization has a large number of photographs of past events. It has produced brochures and pamphlets through offset printing in thirteen languages. It shares minutes and arranges meetings through e-mail. Their individual relationships to different media are varied. Several members have mobile phones used for managing their daily lives and routines. Almost all have desktop computers at home, although several admit to needing assistance to make them functional. Several years ago, RECAA created a website using 'off the shelf' open-source blogging software, but this website was never maintained. Up until this year, the organization had not updated its old equipment. With no permanent location from which to base its activities, practically speaking, the installation of digital equipment in its regular meeting location - a room in a local alternative high school, which RECAA shares with school clubs - posed a security challenge. In 2011, the organization decided to borrow digital equipment, and through a partnership with the Mobile Media Lab and the Atwater Library and Computer Centre, have used these combined facilities and expertise in media production to learn the basics of video editing, plan a website, and engage with social media. RECAA is now in the process of producing a robust bank of digital media assets, which will furnish the unique content for its new 'domain', now under construction (www.recaa.ca). This year, a small grant has allowed the organization to purchase its own camera, computer, and computer software for digital video editing and media production. RECAA has digitized photographs, produced its first video, and is working on a second video. The production of a 'digital locus' - a digital presence that is part of the new electronic means of distribution through the internet - is well underway.

RECAA was drawn to create a digital locus of its own for several reasons. Many of the members of the organization are older, and as they age, the organization's history is 'lost'. Like many community-based organizations, RECAA's legacy as a collective is poorly documented, existing primarily in individual memories or file folders and paper trails in individual members' homes. One of the first things done in the first year was a gathering of photographs from previous events, which were scanned and then re-assembled into a slide show that was first played at an event that RECAA hosted in conjunction with World Elder Abuse Awareness Day a global event held in June 2012. There have also been questions as to how to rejuvenate the group and create new intergenerational connections. As RECAA is located in Montreal there is a desire to connect with other seniors and community organizations outside of the urban centre. These are some of the strategic forces pulling the members of RECAA towards digitization and greater mediatization. There are also interrelated mega-trends that are pushing RECAA to mediatize. As Hepp articulates, the pressure to mediatize and "the 'moulding forces' of the media manifest themselves in processes of interrelation with other forces" (2009, p.150). Since the mid-1990s, the Canadian government has pursued an agenda to create what was in the early days known as the "information highway" and is now known as "the digital economy" (Senate Canada, 2010). As part of a long-term national agenda concerning new technology, which is often positioned as a panacea to the challenges presented by the country's vast geographic area, a technologi- 
cally determinist discourse has become embedded in the Canadian national identity. This discourse of "technological nationalism" (Charland, 1986) is a part of an ongoing rhetoric that other Canadian scholars, such as Vincent Mosco, identify as the "the digital sublime" (Mosco, 2004).

These injunctions to embrace mediatization have significant consequences for seniors at a local level, both for individuals and organizations, even though very little communications policy or research in Canada deals with the specific needs of this demographic cohort (Sawchuk and Crow, 2012). There has been a trend in the government's provision of social services to transform every department's services into one that is first and foremost available through a governmental 'portal to services'. This form of strategic mediatization of administrative services has forced digital compliance for various social groups. If seniors wish to learn about their benefits or rights, they have little choice but to get online (Middleton \& Sorensen, 2005).

Despite this desire for a fully mediatized country, the goal is difficult to meet. While there are reports that more seniors are online (Zickuhr, 2011), own tablet computers (Grenier, 2012) and that seniors in Canada are "becoming wealthier" as a demographic, this not true for all. Many are still living near the poverty line, particularly women who have had less job security, lower wages, smaller pensions, and live longer. Aboriginal elders are amongst the poorest in the country. These are the seniors most in need of the skills to negotiate with government services and agencies online (Statistics Canada, 2007; 2007a; 2010). They may not have access to computers at home. They may not have anyone to turn to for help when they are stuck. As many scholars have pointed out, this tendency to digitization may augment social inequities by providing those with computers and computer skills privileged access to necessary governmental information (Clement \& Shade, 2000). It is for these reasons that specific courses offered for reasonable fees at the Atwater Library and Computer Centre are often attended by older adults.

This mega-trend towards strategic mediatization of governmental services and a belief in prosperity through a "digital economy" is coterminous in the Canadian context with another mega-trend: that of neo-liberalism (Couldry, 2010). Neo-liberalism has brought about a retraction of government from public service, instituted new user fees for such services, cut back severely on progressive local programs in the name of lower taxes, demanded that communities and groups find 'partnerships' with the private sector, promoted the deregulation of markets, rolled back legislation to protect workers, loosened any regulations intended to protect national resources or the environment, and instigated programs with (ironically) public money to promote business and investment, and encouraged state surveillance and security, to name a just few trends at work in Canada over the past decade. These mega-trends also exert pressure on organizations to mediatize in particular ways.

The funding for community-based projects, art, culture, and academic scholarship is increasingly under the injunction to work in a 'partnership model' borrowed from industry and science. In this emerging scenario, digitization is tied to neo-liberalism. Cash-starved 
community groups, which have seen their funding systematically cut, must negotiate this strategic mandate as one potential means of accessing money. As the situation intensifies due to ever-greater 'austerity plans', projects that integrate digital media become part of a tactical measure that community-based organizations such as RECAA are forced to consider. "Get this on tape," says Anne at a session, "I want this on tape: We need core funding." The problem, however, is that core funding is difficult to secure even for those cultural organizations that have received government support over a long period of time (MacDonald, 2012). Add to this recent changes to the laws governing immigration into Canada, which prioritize youth and language skills (Levitz, 2012), and the outlook is dire for activist groups composed primarily of women of colour from various immigrant communities, which possess a target audience of those who often speak neither French nor English. Tactical measures that work within the strategic plans of the current power regime become necessary.

The real-life problems and tensions within this framework become evident at the local level in other ways. While the government supports programs intended to increase digital access (mainly through start-up money for research on digital programs that align with the country's "digital economy" strategy, as well as programs with names like 'New Horizons' that fund small projects by community organizations with senior constituents), there is an irony at work. If a program or workshop is successful, an organization will not typically have access to sufficient funding to repeat it. One must innovate. One must find new partners. One cannot apply for funding for the same program twice. Organizations are expected to find private donors and sponsors or to adopt a consumerist model. Even if specific projects that involve new ways to 'mediatize' and provide 'new' and 'innovative' approaches to the adoption of digital media are created, they cannot be repeated. One must keep innovating. It is for these reasons that some University-based researchers, including those of us working at the Mobile Media Lab, find ways to work creatively within this set of systemic arrangements, identify how to 'pervert' the strategic goals embedded in the new governmental language of neo-liberalism, and collaborate with community-groups to put resources into the hands of important intellectual allies such as RECAA.

RECAA members also understand that they are living in a new communicational social ecology of the digital, and more specifically Web 1.0 and 2.0, which is exerting transformative pressure upon their organization. They are keenly aware of this shift towards mediatization in the communications environment. They may be older, but they do not live in a bubble. They keep in touch with children and grandchildren over mobile phones and computers. Yet their digital skills vary, and those who have a computer do not necessarily know how to maintain it so that it runs without problems. Although they are in their 70s and above, they are deeply intrigued by what technologies can do for them and what they can do with them. They are curious and critical. One RECAA member (aged 92), who was recently given an iPad, stated bluntly, "Kim, I like this iPad thing, but you know, I have been keeping a list of what I think they could improve." Media devices are symbolically coded cultural artifacts ingrained in everyday life. RECAA has decided that it is not viable to opt 
out of digital technology completely if the organization is to communicate across generations, reach out, extend its audience base, and maintain its contemporary relevance. It must find a path that is commensurate with its goals in order to contend with this context and the pressure to mediatize.

In summary, reflecting on this moment of transition within a larger set of 'mega-trends' or 'meta-processes', one can identify a series of specific pressures that both push and pull an organization, such as RECAA, to mediatize its resources, to incorporate social media, and to acquire technologies. Within this scenario, mediatization emerges as a potential survival strategy against these inter-locking pressures. Yet as we will explore in the next section, there are very specific and local tactical negotiations occurring that modulate how these push and pull factors are experienced and negotiated.

\section{The practice of tactical mediatization}

Over the past year, RECAA members have begun to embrace the digital, but they are not passive in their acceptance. One of their primary tactics for mediatization involves maintaining prior practices of communication, drawing upon years of experience with deep and respectful listening and speaking, incorporating an understanding of democratic communication as patient reciprocity, and emphasizing collective decision making in the group. Before deciding what to mediatize and how to mediatize, time is spent pre-planning and finding consensus at face-to-face meetings.

This planning included preliminary discussions to see if our Lab could work together with RECAA in an atmosphere of mutual trust. As Anne, one of RECAA's founders, asked during our first meetings, "How can we get our message out there? We need to understand what this technology can do for us." To address Anne's questions, meetings were held to discuss what digital tools might be appropriate and how these might be integrated into RECAA's pre-existing practices of communication through theatre. Tactical mediatization does not reject communicational practices or other forms of media but instead relies on the integration of discussion and listening into the media-making process.

Maintaining rituals of communication modulates how RECAA has come to learn filmmaking and digital editing. The digital camera was gradually incorporated into the communicational routines that sustain RECAA's ethos. Every session with RECAA begins with one person greeting another, such as "How are you doing, Ethel? Tell me about your week." At the same time as this ritual 'check-in' is going on, cameras are passed from member to member so that each one has a turn at filming and being filmed.

This practice presents several benefits to group members. First, prior forms of exchange are maintained at the same time as the technology is demystified in a hands-on manner. Second, filming in this casual atmosphere around the table gives members a chance to learn different techniques gradually, such as holding the camera, pushing the record button, looking through the screen, zooming in and out, following the action, and framing a shot. 
The camera becomes a familiar item, giving them a chance to cultivate an embodied fluency so that it is less interruptive when used later. The result of these year-long exercises in feeling 'at ease' with both filming and being filmed has resulted in the collection of materials that they can now use for a variety of purposes. This has also resulted in the production of a very specific genre of small-scale, short video documentaries, which we have made with other community groups, called the 'video capsule.'

RECAA recently completed its first five-minute video, 'Respecting Our Elders', which the organization filmed, edited, directed, produced, and screened for World Elder Abuse Awareness Day (WEAAD) in June 2012. All 12 members of the theatre group created the film segments incorporated into the final capsule. The video features the voices of all members of RECAA. Briefly and at different moments, they tell the story of how the organization came into being, explain why it exists and what elder abuse is, and deliberate the effects of the denial of elder abuse in cultural communities. Representatives are included from external partner organizations, and they testify as to the importance of this mandate for their communities. The film takes the form of a simple, direct, short, and intentionally small digital file that can easily be further compressed and placed on the forthcoming RECAA website. 'Respecting Our Elders' is exemplary of RECAA's deliberately slow transition from a very minor and episodic brush with digital media to a more extensive commitment to mediatize its history and integrate digital media and digital storytelling into its theatrical practice and organizational mandate.

In the post-production process the group also learned that the digital is not without challenges. While everyone took turns holding the camera, filming and being filmed, only four members worked on the final editing. RECAA's continual commitment to consultation and negotiation proved vital to their editing practice. When the first set of 'cuts' were made the decisions were discussed collectively, taking into account how to include the wishes of those who were not directly involved in the editing. How to represent RECAA as a group within the constraints of a five-minute film proved to be a challenge.

In subsequent meetings, RECAA began using the camera as a tool within its workshop activities. Filming rehearsals made members aware of how they appear on camera, a process that they did not expect to find helpful. However, they learned that the camera, used judiciously, could complement the development of future scripts and allow them to carefully hone those scripts that they know well. Awareness of their responsibility to their constituency of elders who need to find ways of talking about abuse has meant that there are places and moments when filming is taboo: although they have filmed the presentation of 'Aunt Enid' as a performance for WEAAD, digital videotaping is understood as ethically inappropriate when they are in a home, or residence facility for seniors.

RECAA's growing repertoire of digital skills and tactical use of digital media, such as digital video editing, has sparked engagement with the teenagers who attend the school where RECAA has been given a room to use for their bi-weekly meetings. Ownership of technology, in this context, acts as a mediating link between radically different generations. 
RECAA's initial digitization efforts have already generated new intergenerational projects, such as 'The Golden Feedback Loop', with high school students concerning ageism, intergenerational miscommunication, and intergenerational respect. Indeed, one of the first skits they are developing with high school students addresses how different practices of mediatization, such as wearing a set of headphones and blaring loud music in public places, can bring about misunderstandings between generations.

\section{Discussion: strategic and tactical mediatization}

In his critique of the use of the term 'media logic' on account of its latent technological determinism, Knut Lundby suggests that "it is necessary to specify how various media capabilities are applied in various patterns of social interactions" (2009, p. 117). In the above presentation of the pressures compelling RECAA towards mediatization, one must also acknowledge the ways that a specific set of social actors may deploy, limit, and negotiate this technologized communications agenda and make it their own. And here I turn to the chapter 'Making Do: Uses and Tactics' in Michel de Certeau's Practices of Everyday Life (1988).

De Certeau makes a vital distinction between strategies and tactics. Strategies are the operational procedures implanted by those with economic, social, or political power, who establish rules, create territories of control, and accumulate the necessary knowledge and information - that shape the world in which we live and through which we move. De Certeau identifies the government and the military as examples of institutional forces capable of strategically implementing systems to their advantage and being invested with the legitimacy to administer and demand our compliance. "Strategies are actions which, thanks to the establishment of a place of power (the property of a proper) elaborate the theoretical places (systems and totalizing discourse) capable of articulating an ensemble of physical spaces in which forces are distributed" (de Certeau, 1988, p. 38). In this case study, the governmental injunctions to adopt a digital agenda, to establish private-public partnerships, to generate revenue and become commercial and financially viable. These are all instances when an assemblage of mega-trends form a very loose but extremely powerful system of 'strategic mediatization'.

Tactics are the ways that those who are subordinates within these systems - those who do not immediately and readily benefit and who are left out or are marginalized - can act in order to implement work-arounds to make a system and a technology work for them. RECAA borrows equipment, maintains past practices, and subverts expectations concerning the ability of 'old people' to learn 'new media'. 'Tactics', writes de Certeau, are the 'strategies' of those who do not operate from the same foundations of power (1988, p. 37). These are not necessarily large permanent organizations with their own 'proper' space. "A tactic is a calculated action determined by the absence of a proper locus" (1988, pp. 36-37). Tactical digital learning can be understood as a set of maneuvers or timely interventions made by a precarious and vulnerable group of elders into an existing system of media and 
representations of the elderly. As an organization consisting of older adults, RECAA's use of Forum Theatre breaks the silence surrounding elder abuse and is another example of a non-mediatized tactical move against ageism, a discursive system supported by a culture that valorizes youthfulness and positions the elderly as 'dependents' rather than as productive media makers. RECAA's recent appropriation of digital technologies to document its history and life as an organization, to explore how the media might be made to work for them, and to find ways to sway the digital agenda to include the needs and desires of older adults exemplifies what we might call 'tactical mediatization'.

Notably, tactical maneuvers do not deal with systems of power from the outside. Tactical maneuvers originate from within. They are implemented by social actors who lack resources and must thus operate, as de Certeau says, "blow by blow" (1988, p. 37) in small measures to take advantage of opportunities, such as government grants for new media production, that are not typically targeted to seniors. Organizations that resort to tactics depend on the current systems within which they work yet are unable to gather or accrue huge amounts of resources. Community-based organizations that are engaged in a constant struggle to survive must, in the words of de Certeau, "vigilantly make use of the cracks that a particular conjunction opens in the surveillance of proprietary power. It poaches in them. It creates surprises in them. It can be where it is least expected. It is a guileful ruse" (1988, p. 37).

Community-based organizations like RECAA are engaged in tactics, some successful and some not, to ensure their longevity. Here, however, I wish to draw a minor distinction between tactical mediatization and tactical media. While some activist organizations have adopted the term 'tactical media' to describe media engagements that are disruptive and temporary (Raley, 2009), RECAA do not practice tactical media. The clever performance of New York's Surveillance Camera Players, whose campaigns invite citizens to 'perform' for the security cameras that are a ubiquitous feature of the contemporary mediatized landscape are a good example of tactical media, as are the well-documented antics and interventions of the 'Yes Men'. While it is beyond the scope of this paper to go into this phenomenon, one characteristic of tactical media is its use of pranks to garner media attention. Tactical mediatization, as I have described it here, captures one way that those "without voice" (Couldry, 2010) can continually struggle to make their voices heard. Tactical mediatization, as practiced by RECAA, is a means of participating in the current culture of media by using a range of off-the shelf, small-scale media projects that intervene, contribute, augment, and negotiate this system.

In short, if mediatization, as it is commonly understood, describes an increasing pressure and power of the media in high modernity, asserting itself over the life world (Hepp, 2012), then tactical mediatization denotes one way of describing the search for agency within these systemic forces and pressures. In moments of transition, such as those described in this paper, we may identify both internal and external pressures that compel an organization to mediatize, yet we can also identify ways that organizations adopt, push-back, negotiate, slow-down, or reject the pace of mediatization through their ways of "making do" (de 
Certeau, 1988, p. 35), a making that allows for a meaningful, considered, experimental, and tactical engagement with an assemblage of communication technologies.

\section{Conclusion}

Identifying moments of tactical mediatization reveals how variations and differences in practice exist within long-term or general mega-trends described at a meta-theoretical level. In the case of RECAA mediatization is not merely imposed; it becomes integrated into a unique, customized media-making process that honors the organization's past communicative experiences and core values as a community. It is in this sense that Lundby's pleas for us to understand mediatization from a communications perspective, placing 'social interaction' in the foreground of our research, is crucial for understanding tactical mediatization as it is practiced by individuals and communities. As Lundby writes, "mediatization research should put an emphasis on how social and communicative forms are developed when media are taken into use in social interaction" (2009, p. 117). When mediatization as a process, a system, an order, a logic occurs, it does not suddenly appear out of nowhere, without precedent. It does not insert itself into a blank space. It insinuates itself, or settles, in a definite context that has its own history, practices, morphological structures, and temporalities of communicative action.

Practices of tactical mediatization underline how the pressures to mediatize are shaped by this stubbornness, which the Brazilian geographer Milton Santos calls "rugosities" (Josgrilsberg, 2008). As Josgrilberg so eloquently states in his discussion on the creation of a "digital locus":

\footnotetext{
The digital locus created by information and communication technologies is systematically interwoven with other technical and non-technical possibilities, from the most prosaic ones such as oral communication to high-tech bio-engineering. As popular as it is to portray and differentiate the present historical period as the 'Information Society', or the 'Knowledge Society', previous technical systems and past organizations function as dialectical poles, with no universal historical project at the end. The digital locus fosters the possibilities of movements and these movements reinvent the digital locus in a tension whose outcomes are, perhaps, more unpredictable than they may at first seem (Josgrilberg, 2008).
}

In the case of RECAA, its primary communicational form (Forum Theatre) is not being replaced by a newer form (the digital) that will inevitably supplant the work they do with other communities in person, on location, in intimate settings, in private. Instead, techniques from theatre and the organization's means of working in a highly experimental, yet very careful, manner are mapped onto the specific characteristics of digital media, creating a place from which they can operate and in which they can continue to move. The point is this: RECAA's practices transform the media as technologized communication at the same time as RECAA is transformed as an organization by its presence. In deciding to become 
digital, to mediatize, an active negotiation is taking place in these explorations. In this instance, mediatization does not so much "mould" (Hepp, 2012) as 'modulate', RECAA's pre-existing storytelling practices.

De Certeau says that, in terms of a strategic logic of calculation, "What is counted is what is used, not the ways of using" (1988, p. 35). What is crucial in this case study is not the question of whether mediatization is taking place. The question is how. As consideration of tactical mediatization suggests, we must pay attention to how practices, institutional arrangements, the dynamics of power at play in a particular space, or "digital locus" (Josgrilsberg, 2008) is continually modulated by pre-existing processes in each of these moments, every step of the way.

\section{Notes}

1. This explanation of Forum Theatre and the idea of the "spect-actor" is taken from correspondence with RECAA member Lib Spry.

2. Methodologically, the collaborative projects are motivated by PAR, participatory action research. Research has involved a year of observation and engagement with the organization, including technical training, event planning, and brainstorming at meetings. I have kept field notes and undertaken informal interviews with members.

3. Cultural geographers who study immigration identify factors pushing people away from their current locations and those pulling (or attracting) them towards a specific place.

4. See Anne Caine's interview with RECAA member, Sarah Susan (Susie) Raphals filmed four days before Susie's death http://youtu.be/YT4XOb_OlzE. At Susie's request, Anne used her iPhone to interview Susie about her very strong views on the need for gun control in the United States and later edited it as a short video for Youtube distribution. This is yet another example of RECAA's practice of tactical mediatization.

\section{Acknowledgements}

I would like to thank the members of RECAA for their openness and interest in this paper and for permission to discuss their work in this case study. In particular, I extend my gratitude to Anne Caine, Francine Cytrynbaum, and Lib Spry for their critical reading of this text and their suggestions. Sophie Guérin, MA, in Media Studies has been invaluable as a research assistant on this project, acting as a mentor to us all. This research was made possible through the financial support of the Social Sciences and Humanities Research Council - Partnership Development Grant program. Finally, I would like to express my deepest appreciation to my colleagues in the 'Ageing Communication Media' network, Mireia Fernández-Ardèvol, Line Grenier, Barbara Crow, and Chui Yin Wong for ongoing stimulating discussions (www.mobilities.ca). 
This paper is dedicated to the memory of Susie Raphals (October 18, 1920 - February 9, 2013).

\section{References}

Altheide, D. \& Snow, R. (1979). Media Logic. Beverly Hills, CA: Sage.

Boal, A. (1982 [1979]). The Theatre of the Oppressed. New York: Urizen Books, 1979. Republished by Routledge Press in New York/London in 1982.

Brake, D. (2008) Shaping the 'me' in MySpace: The framing of profiles on a social network site. In Lundby, K. (Eds.). Digital Storytelling, Mediatized Stories: Self-representations in New Media. (pp. 285-300). New York: Peter Lang.

Charland, M. (1986). Technological Nationalism. In Canadian Journal of Political and Social Theory 10/1, 196-220.

Clement, A. \& Shade, L. (2000). The Access Rainbow: Conceptualizing universal access to the information/ communications infrastructure. In M. Gurstein (Ed.). Community Informatics: Enabling Communities with Information and Communications Technologies (pp. 1-20). Hershey, PA: Idea Group.

Couldry, N. (2008). Mediatization or mediation? Alternative understandings of the emergent space of digital storytelling. In New Media \& Society, 10, 373-391.

Couldry, N. (2010). Why Voice Matters: Culture and Politics after Neoliberalism. London: Sage.

de Certeau, M. (1988). The Practice of Everyday Life. Berkeley: University of California Press.

Drotner, K.(2008). Boundaries and bridges: Digital storytelling in education studies and media studies. In Lundby, K. (Ed.), Digital Storytelling, Mediatized Stories: Self-representations in New Media. (pp. 61-84). New York: Peter Lang.

Grenier, Danika. (2012). Younger demographic more a PC than smartphone generation, Deloitte, The Wire Report. Published 12/07/2012. Accessed 18 Dec 2012. Available from: http://www.thewirereport.ca/ news/2012/12/07/younger-demographic-more-a-pc-than-smartphone-generation-deloitte-says/26099.

Hall, S. (1986). "On Postmodernism and Articulation: An Interview with Stuart Hall." Ed. Lawrence Grossberg. Journal of Communication Inquiry. 10.2 (1986): 45-60.

Hepp, A. (2009). Differentiation: mediatization and cultural change. In K. Lundby (Ed.), Mediatization: Concept, Changes, Consequences (pp. 135-154). New York: Peter Lang.

Hepp, A. (2012). Cultures of Mediatization. London: Polity Press.

Hjarvard, S. (2008). The mediatization of society: a theory of the media as agents of social and cultural change. Nordicom Review, 29(2), 105-134.

Hjarvard, S. (Ed.). (2008a), The mediatization of religion: enchantment, media, and popular culture. Northern Lights: Film \& Media Studies Yearbook, vol. 6, Bristol: Intellect.

Hutchins, B and Mikosza, J. (2010). The Web 2.0 Olympics: Athlete Blogging, Social Networking and Policy Contradictions at the 2008 Beijing Games. Convergence. vol. 16 no. 3 279-297.

Innis, H. A. (1951). The Bias of Communication. Toronto: University of Toronto Press.

Josgrilberg, F. (2008). A Door to the Digital Locus: Walking in the City with a Mobile Phone and Michel de Certeau. Wi: Journal of Mobile Media. Last accessed Dec 18, 2012. Available at: http://wi.hexagram. $\mathrm{ca} / \mathrm{p}=35$.

Kaare, B.H. and Lundy K. (2008). Mediatized Lives: Autobiogrpahy and assumed authenticity in digital storytelling. In Lundby, K. (Ed.), Digital Storytelling, Mediatized Stories: Self-representations in New Media. (pp. 105-122) New York: Peter Lang. 
Krotz, F. (2009). Mediatization: a concept with which to grasp media and societal change. In K. Lundby (Ed.), Mediatization: Concept, Changes, Consequences. (pp. 21-40). New York: Peter Lang.

Latour, B. (2005). Reassembling the Social: An Introduction to Actor-Network Theory. Oxford: Oxford University Press.

Levitz, S. (2012). New Immigration System will Favour Younger Workers, Language Skills. Accessed Dec 192012 at http://news.nationalpost.com/2012/12/19/new-immigration-points-system-will-favouryounger-workers-language-skills/Points.

Livingstone, S. (2009). On the mediation of everything. Journal of Communication, 59, 1-18.

Lundby, K. (Ed.). (2008). Digital Storytelling, Mediatized Stories: Self-representations in New Media. New York: Peter Lang.

Lundby, K. (2009) Media Logic: Looking for Social Interaction. In K. Lundby (Ed.), Mediatization: Concept, Changes, Consequences (pp. 1101-122). New York: Peter Lang.

MacDonald, D. 2012. The Cuts Behind the Curtain: How federal cutbacks will slash services and increase unemployment. Accessed may 132013 at http://www.policyalternatives.ca/sites/default/files/uploads/ publications/National\%20Office/2012/01/Cuts_Behind_Curtain.pdf.

McLuhan, M. (1964). Understanding Media: The Extensions of Man. London: Routledge and Kegan Paul.

Middleton, C., \& Sorensen, C. (2005). How connected Are Canadians? Inequities in Canadian households' Internet access. Canadian Journal of Communication, 30(4), 463-483.

Mosco, V. (2004). The Digital Sublime: myth power and cyberspace. Cambridge Massachusetts: MIT Press.

Nybow, L. and Drotner K. Identity, aesthetics and digital narration. In Lundby, K. (Ed.), Digital Storytelling, Mediatized Stories: Self-representations in New Media. (pp. 161-176). New York: Peter Lang.

Ovum Consulting (2012) The Benefit to the Canadian Economy from the Wireless Telecommunications Industries: An Economic Impact Assessment. Report Prepared for the Canadian Wireless Telecommunications Association Last accessed Dec 18, 2012. Available at: http://cwta.ca/wordpress/wpcontent/ uploads/2012/06/Ovum2012.pdf.

Raley, R. (2009). Tactical Media. Minneapolis: University of Minnesota Press.

Sawchuk K. and Crow, B. (2012). Tactical Restriction: Seniors and Cell Phones. In Phillip Vannini et.al. (Eds.). Technologies of Mobility in the Americas, (157-174). New York: Peter Lang Publishing, Inc.

Schulz, W. (2004). Reconstructing mediatization as an analytical concept. European Journal of Communication, 19, 87-101.

Senate Canada (2010) Plan for a Digital Canada. Last accessed Dec 18, 2012. Available at: http://planforadigitalcanada.ca/images/stories/pdf/report.pdf.

Silverstone, R. (2005). The sociology of mediation and communication. In C.J. Calhoun, C. Rojek, \& B.S. Turner (Eds.), The SAGE Handbook of Sociology (pp. 188-207). London: Sage.

Special Senate Committee on Aging (2009) Canada's aging population: Seizing the opportunity. Government of Canada: http://www.parl.gc.ca/40/2/parlbus/commbus/senate/com-e/agei-e/rep-e/AgingFinalReporte.Pdf.

Statistics Canada. (2007). 'A portrait of seniors in Canada.' [Internet] Government of Canada. Accessed 18 Dec 2012. Available from: http://www.statcan.gc.ca/adsannonces/89-519-x/index-eng.htm.

Statistics Canada. (2007a). 'Deaths, 2007.' The Daily, February 23, 2-3.

Statistics Canada. (2010). 'Average income after tax by economic family types.' [Internet] Government of Canada. Accessed 18 Dec 2012. Available from: http://www40.statcan.ca/l01/cst01/famil21a-eng.htm.

Strombeck, Jesper (July, 2008). Four Phases of Mediatization: An Analysis of the Mediatization of Politics. The International Journal of Press/Politics, 13, 228-246.

Thompson, J.B. (1995). The Media and Modernity: A Social Theory of the Media. Cambridge, UK: Polity. 
Article: Tactical mediatization and activist ageing

World Health Organization (2002) Active ageing: A policy framework: Accessed 18 Dec 2012. Available from: http://www.who.int/ageing/publications/active/en/.

Williams, R. (1977). From reflection to mediation. In Marxism and Literature (pp. 95-100). Oxford: Oxford University Press.

Williams, R. (1983). Keywords: A Vocabulary of Culture and Society. London: Fontana.

Zickuhr, K. (2011). A closer look at generations and cell phone ownership. Institution Pew Research Center. Accesed 13 May 3013 http://www.pewinternet.org/Infographics/2011/Generations-and-cell-phones. aspx.

Kim Sawchuk
Professor, PhD

Concordia Universty Research Chair, Mobile Media Studies

Department of Communication Studies

Concordia University, Canada

kim.sawchuk@sympatico.ca 